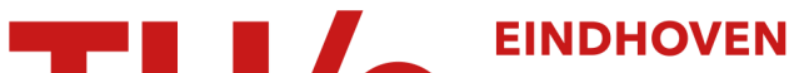 UNIVERSITY OF TECHNOLOGY
}

\section{Self-assembled nanoreactors based on peptides and proteins}

\section{Citation for published version (APA):}

Timmermans, S. B. P. E., \& van Hest, J. C. M. (2018). Self-assembled nanoreactors based on peptides and proteins. Current Opinion in Colloid and Interface Science, 35, 26-35. https://doi.org/10.1016/j.cocis.2018.01.005

DOI:

10.1016/j.cocis.2018.01.005

Document status and date:

Published: 01/05/2018

\section{Document Version:}

Accepted manuscript including changes made at the peer-review stage

\section{Please check the document version of this publication:}

- A submitted manuscript is the version of the article upon submission and before peer-review. There can be important differences between the submitted version and the official published version of record. People interested in the research are advised to contact the author for the final version of the publication, or visit the $\mathrm{DOI}$ to the publisher's website.

- The final author version and the galley proof are versions of the publication after peer review.

- The final published version features the final layout of the paper including the volume, issue and page numbers.

Link to publication

\section{General rights}

Copyright and moral rights for the publications made accessible in the public portal are retained by the authors and/or other copyright owners and it is a condition of accessing publications that users recognise and abide by the legal requirements associated with these rights.

- Users may download and print one copy of any publication from the public portal for the purpose of private study or research.

- You may not further distribute the material or use it for any profit-making activity or commercial gain

- You may freely distribute the URL identifying the publication in the public portal.

If the publication is distributed under the terms of Article 25fa of the Dutch Copyright Act, indicated by the "Taverne" license above, please follow below link for the End User Agreement:

www.tue.nl/taverne

Take down policy

If you believe that this document breaches copyright please contact us at:

openaccess@tue.nl

providing details and we will investigate your claim. 


\title{
Self-assembled nanoreactors based on peptides and proteins
}

\author{
Suzanne B. P. E. Timmermans and Jan C. M. van Hest* \\ Eindhoven University of Technology, P.O. Box 513 (STO 3.31), 5600 MB Eindhoven, The Netherlands \\ KEYWORDS: catalysis, self-assembly, supramolecular interactions, enzyme mimic, organelle mimic, compartmentalization, \\ nanoreactor, catalytic fiber, catalytic hydrogel, protein nanocage
}

\begin{abstract}
Catalyst function is tightly controlled in biology by means of compartmentalization and positional assembly. Inspired by these innate strategies researchers have developed self-assembled structures that mimic natural control over catalytic activity by employing polymer-, lipid-, DNA-, peptide- and protein-based systems. Here, recent developments in self-assembled peptide- and protein-based nanoreactors will be discussed. This review will cover nanoreactors that are generated by either positional control of catalysts on fibrous supramolecular structures or confinement of catalysts inside protein nanocages. The focus will be on the selfassembly mechanisms that are involved in the formation of these catalytic systems.
\end{abstract}

\section{INTRODUCTION}

Inspired by the strategies employed by living cells to control multi-step enzymatic processes in a temporal and positional manner, researchers have become interested in positional assembly and compartmentalization of catalysts. Regulation is crucial for proper cellular function, hence cells contain membrane-encapsulated organelles and scaffold proteins to achieve this spatiotemporal control. Importantly, this regulation allows for efficient tunneling of substrates between enzymes in a cascade, prevents toxic effects caused by interference of substrates of incompatible pathways and controls the flux of substrate molecules through metabolic networks via feedback and feed forward mechanisms. Scientists have attempted to mimic biological encapsulation and scaffolding systems by using a plethora of different synthetic and bio-inspired strategies to create nanoreactors [1-4]. For example, compartmentalization of enzymes was achieved in lipid- and polymer-based vesicles, protein and DNA nanocages [5], and repurposed bacterial microcompartments [6-8] and cellular organelles. On the other hand, DNA and protein scaffolds, and self-assembled fibrous structures have been employed to mimic the function of natural scaffold proteins.

The motivations for imitating encapsulation and positional control of catalyst assembly can be found in both fundamental and applied science. Of course, an artificial enzyme or organelle mimic can be used to further our understanding of enzyme, organelle and cellular function. However, a biomimetic nanoreactor can in addition be employed for enhancement of selectivity and efficiency of catalysts with applications in biomanufacturing or green chemistry. Perhaps most intriguingly, a synthetic catalytic system can be utilized in the construction of artificial organelles with the potential to correct defective cells in a therapeutic approach or even expand the functionality of natural cells.

Here, we will review recent developments regarding selfassembled peptide- and protein-based nanoreactors as these materials encompass functionality, flexibility and robustness. Both systems that order catalysts with nanometer precision along a self-assembled structure and systems in which enzymes are encapsulated in confined spaces will be discussed. As the focus of this review is on self-assembled systems, nanoreactors in which catalysts are immobilized or covalently attached to a scaffold [2] are outside the scope of this review. Rather than giving a complete overview of selfassembled peptide- and protein-based nanoreactors that have been developed, we limit ourselves to those systems in which recently most progress has been made and that are most promising for further development, namely organization of catalysts on fibrous structures and confinement of catalysts inside protein nanocages. An overview of the systems that will be described in this review is provided in Table 1. We will discuss the self-assembly mechanisms involved, and the scope and limitations of these nanoreactors. In section 2 catalytic peptide fibers and peptide- and proteinbased hydrogels will be discussed, while the third section elaborates on enzyme encapsulation in protein and viral nanocages. In a concluding section we will give an outlook on the potential of these systems for the future.

\section{NANOMETER-SCALE POSITIONING OF CATALYSTS ON SELF-ASSEMBLED FIBROUS STRUCTURES}

Inspired by fibrous structures found in nature, self-assembled peptide and protein fibers and hydrogels have caught the attention of scientists as convenient scaffolding materials for the positional assembly of catalytic species. In these systems, a simple subunit is designed in such a way that it can arrange itself into fibrous bundles with catalytic activity. As a strength of this strategy, the small subunit is fairly easy to produce, while the resulting supramolecular structures can be quite complex and can display novel functionalities. In addition, the supramolecular nature of the fibrous structures results in a dynamic system that can optimize itself via for example molecular imprinting, as opposed to covalently 
formed fibers. In sections 2.1 and 2.2 the various peptideand protein-based catalytic fibers and hydrogels will be discussed more comprehensively.

\subsection{Catalytic fibers}

Generally, catalytic fibers are peptide-based nanoreactors that are generated by the self-assembly of rationally designed peptide sequences and which receive their catalytic activity from the spatial arrangement of specific amino acids in the sequence. Based on their specific self-assembly mechanisms, peptide-based catalytic fibers can be divided into two classes, namely amphiphilic and amyloid-like peptides, which will be discussed respectively in sections 2.1.1 and 2.1.2.

\subsubsection{Catalytic fibers based on peptide amphiphiles}

Catalytic fibers in this class are constituted by a short peptide sequence attached to a hydrophobic moiety (Figure 1). In most systems, the hydrophobic portion of the amphiphile is composed of an alkyl chain of 8 to 16 carbons in length [9-12] although bolaamphiphilic peptides [13] and peptide amphiphiles with aromatic domains are also known [14]. Despite the catalytic applications of the specific fibers differing substantially, the origin for catalysis generally can be found in the peptide segment. A (combination of) specific amino acid(s) can activate a reaction either directly $[11,12,14]$ or indirectly via coordination to a metal catalyst $[9,10,13]$.

The basis for self-assembly of peptide amphiphiles into catalytic nanofibers can be found in both the peptide sequence and the hydrophobic tail. Guler and Stupp demonstrated that both segments need to be present in order to allow successful self-assembly into nanofibers with a diameter of $7 \mathrm{~nm}$ and a length up to several micrometers [11] . Of four similar compounds, only the compound that contained an alkyl chain ánd a peptide fragment facilitating $\beta$-sheet formation, was able to self-assemble into nanofibers. Therefore, $\beta$-sheet formation of the peptide domains combined with hydrophobicity-driven aggregation of the alkyl chains is the most probable mechanism of nanofiber self-assembly of these peptide amphiphiles.

More recent studies confirmed these findings and added to our knowledge of peptide amphiphile assembly into catalytic fibers. For example, it was revealed that the alkyl tails are tightly packed in a hydrophobic core that is surrounded by the peptide domain $[9,10,12]$, which allows easy access for interacting metal catalysts [9] or substrates [12]. In addition, novel self-assembly mechanisms were discovered [13,14]. A bolaamphiphile composed of L-glutamate and a 14-carbon alkyl chain was demonstrated to self-assemble into singlewalled helical nanotubes that could associate with several metals to yield very efficient catalysts for asymmetric reactions [13]. Alternatively, a peptide amphiphile based on $\mathrm{N}$ fluorenylmethoxycarbonyl (Fmoc) diphenylalanine assembled into nanofibers with mixed $\alpha$-helix and $\beta$-sheet structure [14]. Moreover, co-assembly of Fmoc-FFX tripeptide amphiphiles with $X$ representing a Ser, His or Asp residue, resulted in the formation of a complete catalytic triad that displayed esterase activity (Figure $\mathbf{1 b}$ ). Optimization of the organization of the catalytic centers via molecular imprinting enhanced both the activity and selectivity of these peptide fibers. Interestingly, peptide amphiphile-based nanofibers have been recently introduced into novel biomaterials in order to introduce biocatalytic activity $[15,16]$. Most importantly, all these examples indicate that self-assembly of the peptide amphiphiles is essential to catalysis. Explanations for this are either a high density of catalysts presented at the surface of the nanofiber [11][13], chirality in the peptide assembly [13], or the presence of a hydrophobic domain that efficiently accommodates the substrate in close proximity to the reactive site [12].

\subsubsection{Amyloid-like catalytic peptide fibers}

In addition to peptide amphiphiles, repetitive peptide sequences of alternating polar and apolar residues have the propensity to form nanometer scale fibers (Figure 1). These kind of peptide nanofibers are derived from amyloid fibers that were initially only associated with disease [17]. However, more recently it was appreciated that these fibers could be assembled out of simple short peptides in a supramolecular fashion, opening new doors for the generation of complex protein-like structures, such as enzyme mimics.

Amyloid-like catalytic nanofiber self-assembly starts with assembly of short peptide sequences into $\beta$-sheets via hydrophobic interactions [17], where individual $\beta$-strands can be lined up in an anti-parallel fashion [18,19], but are most commonly parallel aligned [19-24]. Hydrogen-bonding as well as hydrophobic and electrostatic interactions drive further assembly into stable peptide nanofibers of approximately $10 \mathrm{~nm}$ width and with lengths of several hundred nanometers [17]. Generally, the amyloid peptide sequence is sufficient to induce self-assembly into fibers, although some peptides require the presence of metal ions in order to selfassemble [24].

The peptide sequence not only enables the formation of supramolecular structures, but is also essential for the catalytic activity of the assembled fibers. Rufo and co-workers [20] developed the LKLKLKL $\beta$-sheet forming motif into a supramolecular catalytic system by substitution of the polar and apolar residues. Exchange of the Lys residues at positions 2 and 4 with His, allowed for the association of $\mathrm{Zn}^{2+}$ as a cofactor for esterase activity, while substitution of the apolar Leu into Val and Ile increased the catalytic activity. The latter effect was caused by the $\beta$-sheet promoting character of the Val and Ile residues which could be further enhanced by exchange of the Lys at position 6 with an amyloid-promoting Gln. This yielded the Ac-IHIHIQI- $\mathrm{NH}_{2}$ peptide as the most catalytically active one. More recently, a very similar system was developed by Al-Garawi and colleagues [19]. They compared the esterase activity of amyloid fibers that were assembled from either a 7-mer Ac-IHIHIYI-NH $\mathrm{NH}_{2}$ or an 11-mer Ac-IHIHIYIHIHI-NH ${ }_{2}$ peptide with double $\mathrm{Zn}^{2+}$ binding capacity and found that the nanofibers consisting of the shorter peptide were more catalytically active in the presence of $\mathrm{Zn}^{2+}$ ions than the fibers that were assembled from the longer peptide. This finding demonstrated that although the presence of $\mathrm{Zn}^{2+}$ is essential for esterase activity 


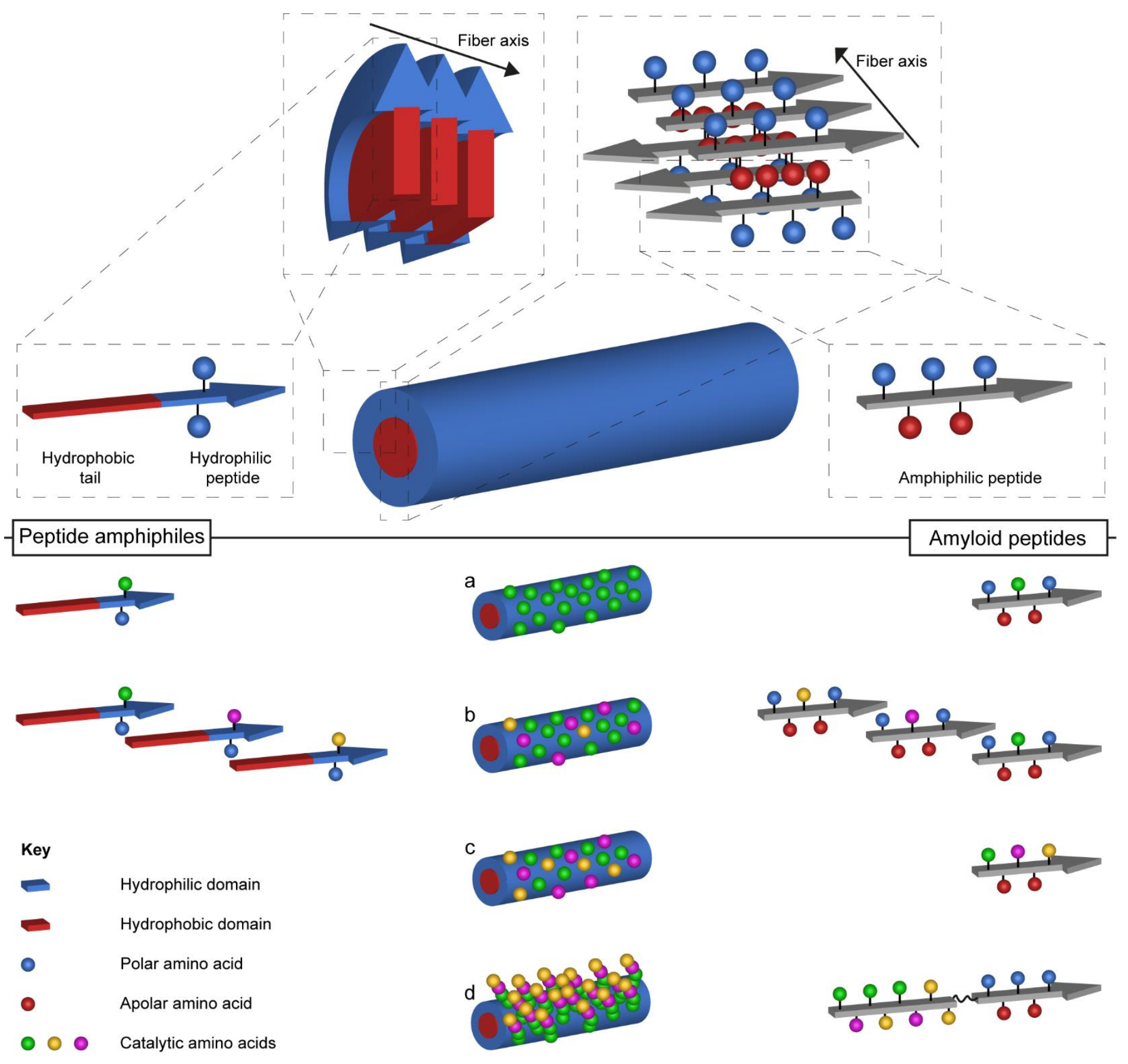

Figure 1: Self-assembly of catalytic peptide nanofibers. The top panel schematically depicts the arrangement of individual peptide amphiphiles or amphiphilic peptides in the fiber structure. In the bottom panel origins of catalytic activity are detailed: (a) one polar amino acid is substituted with a catalytic residue to give rise to nanofibers with catalytic activity; (b) multiple similar peptides with different catalytic residues co-assemble into fibers with multiple catalytic activities; (c) multiple polar residues are substituted with catalytic amino acids within a single amphiphilic peptide sequence to give rise to nanofibers containing multiple catalysts; (d) a catalytic sequence is fused to an amphiphilic peptide to generate a nanofiber that displays the catalytic sequence on its surface.

of the nanofibers, the incorporation of two $\mathrm{Zn}^{2+}$ ions per peptide instead of one can disrupt the active site and reduce catalytic activity.

$\mathrm{Xu}$ and coworkers [24] designed an Ac-FFACD-OH 5mer peptide sequence that relied on $\mathrm{Ag}^{+}$ions for self-assembly into nanofibers. As was the case in the systems described above, the presence of the metal ion was vital to catalytic activity of this system, although the mechanism was completely different. The Cys residue in the peptide sequence reduced the $\mathrm{Ag}^{+}$ions, while the complete fiber structure acted as a template for the formation of ultrafine Ag nanoparticles (AgNPs). The combined assembly of peptide fibers and AgNPs was catalytically active in the reduction of 4-nitrophenol, methyl orange, methylene blue and rhodamine B. Further adding to the catalytic diversity of amyloid fibers, a 
complete serine protease catalytic triad was incorporated into a single fiber-forming peptide sequence by Wong and coworkers (Figure 1c) [22]. The peptide sequence AcFGFHFSFDF- $\mathrm{NH}_{2}$ contains the polar His, Ser and Asp residues of the serine protease active site as well as a Gly residue that was introduced for stabilization of the reaction intermediate. The assembled fibers demonstrated good amidolytic activity towards L-alanine p-nitroanilide, while bulkier substrates could not diffuse as readily between the $\beta$-strands and were thus transformed less efficiently.

Perhaps more convenient for the introduction of multiple catalytically important residues is a system in which catalytic residues are located outside of the self-assembling sequence (Figure $1 \boldsymbol{d}$ ). By attaching a catalytic Lys residue to the N-terminal end of an amyloid sequence derived from Alzheimer's A $\beta$-peptide, Omosun and coworkers generated the Ac-KLVFFAL-NH 2 7-mer that was capable of self-assembly into nanofibers with catalytic activity towards dehydrative oligomerizations and retro-aldol reactions [18]. Substitutions of the Val and Leu residues at position 3 and 7 respectively, allowed for control over the surface structure of the nanotube, which influenced catalysis. In an alternative system, Zhang and colleagues fused a catalytic residue to a self-assembling peptide via a two-residue (SG) flexible linker, yielding the 14-mer Ac-XSGQQKFQFQFEQQ- $\mathrm{NH}_{2}$ where $\mathrm{X}$ represents an Arg or His residue [21]. Most interestingly, co-assembly of Arg and His containing peptides (Figure $1 b$ ) yielded fibers containing both the His residue for hydrolytic activity and the substrate transition state stabilizing Arg. The importance of choosing the correct peptide platform for the display of the catalytic domains was demonstrated more recently [23]. Fusion of a 14-mer catalytic sequence to the FFKLVFF amyloid sequence eventually yielded peptide nanofibers with hydrolytic activity. Most strikingly, fusion of the same catalytic sequence to a collagen sequence $(\mathrm{GPP})_{10}$ yielded supramolecular assemblies without significant catalytic activity. This demonstrates the importance of the amyloid domain for catalysis: not only the crowding effect caused by assembly, but also the presence of a hydrophobic pocket, which is absent in the collagen assembly, are key factors in catalytic activity of amyloid-based peptide nanofibers.

\subsection{Catalytic hydrogels}

When fibers obtain the ability to entrap an aqueous solvent, a hydrogel is formed. The resulting fibrous network structure can be physically stabilized by supramolecular interactions [25], or via protein-protein or protein-ligand interactions, in case of crosslinked protein networks. Sections 2.2.1 and 2.2.2 will elaborate on the self-assembly principles of catalytic peptide- and protein-based hydrogels respectively.

\subsubsection{Peptide-based catalytic hydrogels}

Although the presence of peptide hydrogelators in literature is steadily increasing [25], still only a handful of peptide-based hydrogels that demonstrate catalytic activity are known today. Rodríguez-Llansola and coworkers were the first to report on enhanced catalytic activity after peptide- based supramolecular gelation [26,27]. Their peptide gels were composed of amphiphiles [27] or bolaamphiphiles [26] of Pro-Val dipeptides attached to an alkyl chain and could catalyze direct aldol reactions in water and Henry nitroaldol reactions in organic solvents, respectively. In both of these systems hydrogen bond formation between the peptide domains of the amphiphiles resulted in the formation of aggregates with stacked alkyl chains. The proline residue was responsible for catalytic activity. Developing these systems further, it was established that the good catalytic properties of the hydrogels were the result of bringing catalytic moieties in close proximity as well as of the formation of hydrophobic pockets in the fibrous aggregates [28]. This is in agreement with what was discussed for catalytic amyloidlike fibers in section 2.1.2 [23] and was further confirmed by comparing the catalytic activity of very similar hydrogels based on peptide amphiphiles with and without alkyl tails [29]. Only hydrogels that were composed of peptide amphiphiles that contained an alkyl chain, and thus a hydrophobic domain, were capable of efficient catalysis of the aldol reaction of cyclohexanone and 4-nitro-benzaldehyde in water. This was contributed to the fact that a hydrophobic pocket could solubilize the substrates in close proximity to the catalytic site.

Peptide-based hydrogels were further developed to contain multiple catalysts (Figure $2 \boldsymbol{a}$ ) $[30,31]$. By combining a bolaamphiphilic succinate containing alkyl-peptide (SucVal8) with an amphiphilic proline containing alkyl-peptide (ProValDoc), a hydrogel network was generated that was composed of two distinct types of fibers [30]. As a result the mutually incompatible acid and base catalysts were spatially separated, which allowed for catalysis of tandem deacetalization-aldol reactions. However, self-sorting of the hydrogel network induced a high degree of competition between the acid and base catalysts for the anti-selective asymmetric Mannich reaction [31]. This could be prevented by reducing the concentration of $\mathrm{SucVal} 8$ while maintaining the concentration of ProValDoc. A SucVal8/ProValDoc ratio of $1: 6$ resulted in a sol-gel system containing a hydrogel network of ProValDoc fibers entrapping water and soluble SucVal8. As a result, cooperation between the soluble acid catalyst and the base catalyst in the fibers increased the selectivity of the reaction. Both of these examples illustrate the strength of peptide-based catalytic hydrogels for the development into mimics of enzymatic pathways as well as competing and cooperating enzyme networks.

\subsubsection{Protein-based catalytic hydrogels}

In parallel with what was discussed for peptide-based hydrogels in section 2.2.1, protein-based hydrogels are gaining interest in literature. Although catalysis is generally not the main topic [32], a few interesting examples of catalytic protein-hydrogels were reported in literature quite recently [3335]. In these systems crosslinking was noncovalent and achieved via oligomerization of specific protein domains, such as the trimeric CutA protein $[33,34]$ or homodimeric phosphite dehydrogenase (PTDH) [35]. Furthermore whole enzymes were incorporated in protein-based systems, as opposed to the catalytic peptide-based hydrogels discussed in section 2.2.1. Hereto different strategies were employed, 
a<smiles>CCCCCCCCCCCCNC(=O)[C@@H](NC(=O)[C@H]1CCCN1)C(C)C</smiles><smiles>CC(C)[C@H](NC(=O)CCC(=O)O)C(=O)NCCCCCCCNC(=O)[C@@H](NC(=O)CCC(=O)O)C(C)C</smiles><smiles>CC(C)[C@H](NC(=O)[C@H]1CCCN1)C(=O)NCCCCCCCNC(=O)[C@H](NC(=O)C1CCCC1)C(C)C</smiles><smiles>C1CCCCC1</smiles>

SucVal8

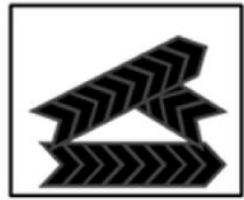

Self-Sorting
ProValDoc

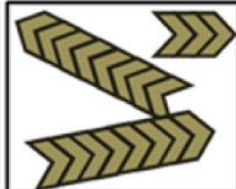

Sol-Gel

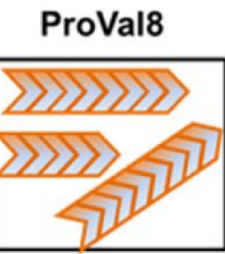

Co-assembly
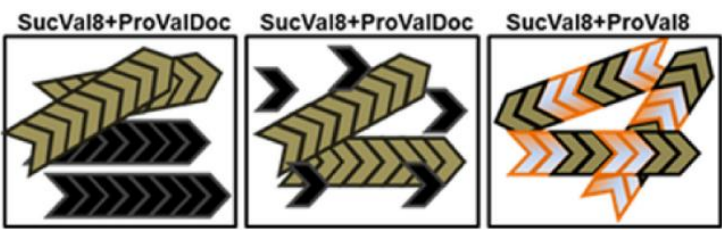

b

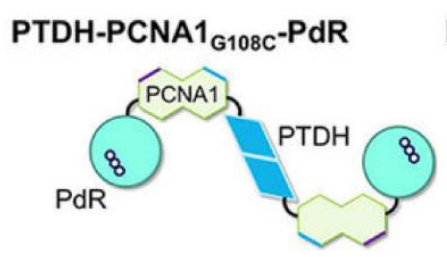

PTDH-PCNA2 L171C -PdX

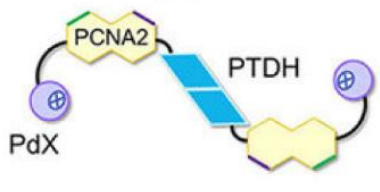

PTDH-PCNA3 ${ }_{\text {R112C/T180C }}$-P450cam

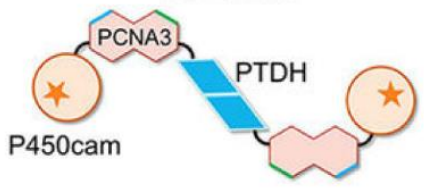

$\downarrow$

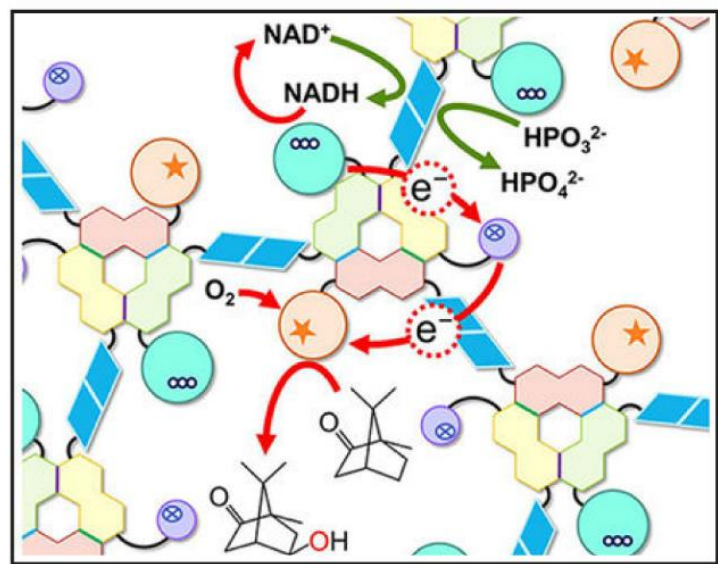

Figure 2: Self-assembly of catalytic peptide- and protein-based hydrogels. (a) Molecular structures of three peptide-based gelators and their self-assembled catalytic hydrogel networks. (b) Three protein-based gelators self-assemble into a catalytic hydrogel network. (a) Reproduced with permission [31]. Copyright, 2017, Wiley-VCH Verlag GmbH \& Co. KGaA, Weinheim; (b) Reproduced with permission [35]. Copyright, 2015, Nature Publishing Group

such as entrapment in the hydrogel network [33], fusion to docking proteins and docking station peptides [34] or direct fusion to cross linker proteins [35].

A very interesting system was recently developed by Nagamune and colleagues (Figure 2b) [35]. Hydrogel formation was dependent on the formation of a supramolecular catalytic complex which was subsequently cross-linked. Cytochrome $\mathrm{P} 450$ monooxygenase (P450) and its redox partners putidaredoxin $(\mathrm{PdX})$ and putidaredoxin reductase $(\mathrm{PdR})$ were fused to the three distinct subunits of proliferating cell nuclear antigen (PCNA). These three components could self-assemble into a trimeric catalytic complex. Fusion of the PTDH protein to the individual PCNA fusion proteins allowed for cross-linking of the supramolecular complexes into a catalytic hydrogel. PTDH did not only function as a cross-linker in this system, but in addition supplied PdR with NADH in the presence of phosphite and NAD ${ }^{+}$. PdR could subsequently transform $\mathrm{NADH}$ in electrons, which were transferred to $\mathrm{P} 450$ by $\mathrm{PdX}$. P450 in turn catalyzed monooxygenation reactions in the presence of oxygen. Most interestingly, the authors demonstrated that the hydrogel was reusable for at least three catalytic cycles, indicating the great power of a catalytic hydrogel network.

\section{CONFINEMENT OF CATALYSTS INSIDE SELF- ASSEMBLED NANOSTRUCTURES}

In addition to positioning catalysts on a nanostructure, encapsulation inside a cage-like system can be employed to compose a nanoreactor. A wide variety of protein nanocages with different shapes and sizes can be found in nature [36]. These structures are self-assembled from several tens to hundreds of subunits and their robustness and uniformity makes them very suitable for nanoreactor development. Although some rod-like protein nanocages have been used as a scaffold for enzyme immobilization [37-41], similar to the positioning of catalysts on the fibrous structures that were discussed in section 2, enzymes are more commonly encapsulated inside icosahedral protein nanocages. Additionally, the confined environment that is created in these catalytic systems can improve efficiency and selectivity of conversions. As such, researchers have used both protein-derived and virus-derived protein nanocages in the generation of novel nanoreactors via enzyme encapsulation, which will be detailed in sections 3.1 and 3.2.

\subsection{Protein-derived nanoreactors}

\subsubsection{Ferritins}


Ferritins are very suitable candidates for the production of nanoreactors that encapsulate a metal catalyst due to their natural iron storage capacity. Assembled out of 24 subunits, ferritins are hollow spheres with inner and outer diameters of $8 \mathrm{~nm}$ and $12 \mathrm{~nm}$ respectively. The ferritin cavity can not only accommodate a striking 4500 iron atoms as a compact mineral but was also demonstrated to incorporate other metal ions and complexes. High stability of the ferritin cage at temperatures reaching up to $80{ }^{\circ} \mathrm{C}$ and in a $\mathrm{pH}$ range from 2-11 adds to its suitability for nanoreactor production even further $[42,43]$.

Having such favorable properties, ferritins were used for the production of various metal-based and nanoparticlebased nanoreactors [42,43], although recent developments are limited. Nonetheless, ferritin-based nanoreactors have already been employed in a plethora of applications. For example, by incubating apoferritin with $\mathrm{Pd}^{2+}$-salts, palladium nanoparticles (PdNPs) were produced inside the ferritin core [44]. These PdNPs with uniform size of $5 \pm 1 \mathrm{~nm}$ catalyzed the oxidation of various primary and secondary alcohols in aqueous environments. In a more recent example, the ferritin cage was used as a template for the biomineralization of manganese oxide [45]. These nanoparticles were generated by a comproportionation reaction between $\mathrm{Mn}^{2+}$ and $\mathrm{MnO}_{4}$ inside the ferritin cage. By altering the $\mathrm{pH}, \mathrm{O}_{2}$-level and reactant ratio the manganese oxide mineral and its properties could be adjusted. In another study ferritin was used as a template for the formation of gold nanoparticles [46]. Most interestingly, the ability of ferritin to accommodate metals and nanoparticles was quite recently demonstrated to be beneficial in a biological system [47]. Dissociation of the apoferritin cage, followed by incubation with $4.5 \mathrm{~nm}$ nanoceria particles and subsequent reconstruction of the protein shell rendered the nano- $\mathrm{CeO}_{2}$ particles inside the nanocage. This yielded a Super Oxide Dismutase (SOD) mimic with excellent reactive oxygen species (ROS) scavenging properties: the apoferitin- $\mathrm{CeO}_{2}$ complex scavenged 3.5 times more ROS than the control SOD. When applied in a live-cell system, the ferritin cage enhanced the uptake of nanoceria and in addition relieved oxidative stress of the cells more efficiently than free nano- $\mathrm{CeO}_{2}$. This is very promising for the use of ferritin nanoreactors for biological applications.

\subsubsection{Chaperonins}

Quite recently, chaperonins caught the attention of Bruns and colleagues for the use as nanoreactor capsules [48-50]. The thermosome (THS), a group II chaperonin, was developed into a nanoreactor for atom-transfer radical polymerization (ATRP). The spherical THS protein cage with an outer diameter of $16 \mathrm{~nm}$ can be formed by self-assembly of eight $\alpha$ and eight $\beta$ subunits. In contrast to most other protein nanocages, the THS cage contains two inner cavities and can consume ATP to cycle between open and closed states. Most importantly, the open conformation allows macromolecules to enter and leave the inner cavities. This renders THS not only very suitable for its native function, namely maintaining proper folding of proteins, but also for the production of polymers in the inner cavities, followed by release in solution.
The first nanoreactor based on THS employed a $\mathrm{Cu}^{2+}$-catalyst for ATRP [48]. In order to entrap the catalyst, a cysteine was introduced on the inside surface of the $\beta$-subunits. A multiamine ligand was then attached via thiol-maleimide chemistry and could subsequently complex $\mathrm{Cu}^{2+}$ ions inside the cavities of the THS nanocage. Addition of initiator, monomer and ascorbic acid induced the ATRP reaction, which yielded poly( $N$-isopropyl acrylamide) (NiPAAm) of low molecular weight and polydispersity. These beneficial properties could be contributed to the confinement of the reaction by the THS nanocage. More recently, the $\mathrm{Cu}^{2+}$ catalyst was replaced by a biocatalyst [49]. The ATRP-catalyzing enzyme horseradish peroxidase (HRP) was incorporated in the THS cavity via covalent attachment to the $\beta$-subunits in a similar way as the $\mathrm{Cu}^{2+}$-catalyst before. HRP could catalyze the formation of poly(ethylene glycol) methyl ether acrylate with the same beneficial properties as the NiPAAm generated by the $\mathrm{Cu}^{2+}$-based THS nanoreactor. This really demonstrates the strength of the THS chamber for production of monodisperse polymers.

In addition to producing polymers, the THS nanocage can be used for biomineralization, despite this protein complex lacking metal ion binding sites. Conjugation of the dendritic poly(amidoamine) (PAMAM) polymer to the inner surface of THS enabled the formation of gold nanoparticles (AuNPs) inside the THS cavities [50]. Hereto the THSPAMAM conjugates were incubated with $\mathrm{HAuCl}_{4}$ and subsequently exposed to $\mathrm{NaBH}_{4}$ to reduce the gold. By varying the gold ion concentration and the number of loading and reduction cycles larger and smaller monodisperse AuNPs could be obtained with diameters of $4.0 \pm 1.5 \mathrm{~nm}$ and $2.4 \pm$ $1.0 \mathrm{~nm}$ respectively. This work demonstrated that in principle any protein cage can be used for biomineralization of metal nanoparticles.

\subsubsection{Lumazine synthetase}

Hilvert and co-workers have focused on yet another protein nanocage and developed a lumazine synthase (AaLS) complex into versatile nanoreactors [51-55]. Naturally, AaLS is a spherical cage formed by self-assembly of $60 \mathrm{sub}-$ units with internal and external diameters of $8 \mathrm{~nm}$ and $15 \mathrm{~nm}$ respectively and $T=1$ icosahedral symmetry [42]. However, 180 subunits of an engineered AaLS-13 variant could selfassemble into icosahedral particles with $T=3$ symmetry and inner and outer diameters of $25 \mathrm{~nm}$ and $36 \mathrm{~nm}$ respectively [51]. The engineered variant contained negatively charged residues on its inner surface which facilitated entrapment of up to 100 copies of a positively charged GFP(36+) variant per protein cage based on charge complementarity. It was further demonstrated that two distinct positively charged fluorescent proteins, GFP(36+) and TOP(36+), were encapsulated at once while presenting Förster resonance energy transfer (FRET) [52].

The GFP(36+)-tagging system was used to load AaLS cages with active enzymes [53]. A simple fusion of the enzyme of interest to the positively charged GFP(36+) was sufficient for encapsulation of approximately 45 enzymes per nanocage. Unfortunately, loading of the enzymes in the 
AaLS core was complicated for negatively charged and oligomeric enzymes. In addition, confinement of the enzymes inside the AaLS cages did not result in enhanced enzyme activity. Nonetheless, the same strategy was used to encapsulate the peroxidase APEX2 in AaLS [54]. This yielded nanoreactors for polymerization of 3,3-diaminobenzidine in the presence of $\mathrm{H}_{2} \mathrm{O}_{2}$. The polymers that were produced had desirable properties such as homogeneity in size and shape, which was attributed to their association with the AaLS cage. In consecutive work two active enzymes were co-encapsulated in AaLS capsids (Figure 3a) [55]. Hereto, the enzymes ribulose-1,5-bisphosphate carboxylase/oxygenase (RuBisCO) and carbonic anhydrase (CA) were genetically fused to $\operatorname{GFP}(36+)$ and TOP(36+) respectively. Mixing of both fusion proteins with AaLS yielded dual-enzyme nano a
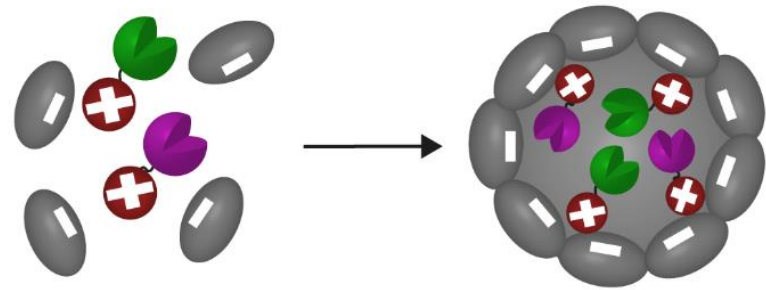

b
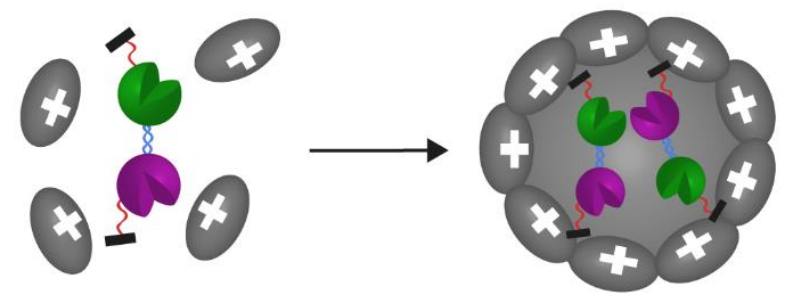

C
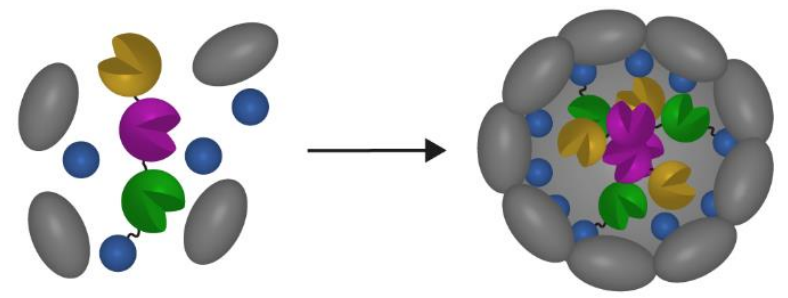

d

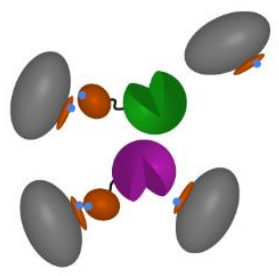

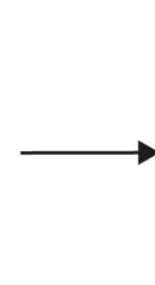

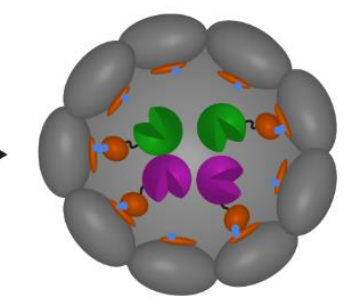

Figure 3: Strategies to achieve encapsulation of multiple enzymes inside protein nanocage-based nanoreactors. (a) A genetic fusion of the enzymes of interest to a positively supercharged protein facilitates encapsulation based on electrostatic interactions with negatively charged cage proteins. (b) Complementary DNA tags (light blue) assist the assembly of multiple enzymes, while negatively charged DNA tags (red) facilitate self-assembly of capsid proteins with a cationic interior. (c) A three enzyme fusion is genetically fused to an MS2 scaffold protein (blue spheres). During self-assembly, the capsid encapsulates scaffold proteins with attached enzymes. (d) Genetic fusion of a SpyTag peptide to a coat protein enables covalent attachment of enzyme-SpyCatcher fusions to the interior of a self-assembling protein nanocage. -reactors as confirmed by FRET between the fluorescent tags. These nanoreactors functioned as carboxysome mimics although quite disappointingly, encapsulation of $\mathrm{CA}$ and $\mathrm{Ru}-$ BisCO in the AaLS cages did not enhance the efficiency of the enzymatic pathway. Therefore it appears that the AaLS nanocage improves enzyme function only by stabilizing the encapsulated proteins.

\subsection{Virus like particle-based nanoreactors}

\subsubsection{Cowpea chlorotic mottle virus}

The cowpea chlorotic mottle virus (CCMV) is an icosahedral plant virus that comprises an RNA genome surrounded by a protein capsid assembled out of 180 coat proteins with a diameter of $28 \mathrm{~nm}$ and $T=3$ symmetry. An interesting property of this virus is that its capsid can be disassembled at $\mathrm{pH}$ 7.5 into 90 protein dimers and RNA and, after removal of the RNA, subsequently reassembled at pH 5.0. When enzymes or other catalysts are present during reassembly they can be encapsulated in the CCMV capsids [56,57]. Although this encapsulation approach is attractive due to its simplicity, loading of enzymes is generally low [56].

Various strategies have been followed to improve the encapsulation efficiency of enzymes inside CCMV capsids [58-60]. One method used comprised the genetic fusion of complementary coiled-coil peptides to both the N-terminus of the CCMV coat protein and the enzymatic cargo [58]. Heterodimerization of the coiled coils during capsid assembly at $\mathrm{pH} 5.0$ resulted in efficient non-covalent binding of Candida antarctica lipase B (CalB) to the interior of the CCMV capsid. Interestingly, this system was used to demonstrate that confinement of enzymes inside CCMV capsids increases the catalytic activity due to an increase of the local concentration of the encapsulated enzyme $[58,61]$. In another approach an enzymatic coupling strategy was employed to ensure a covalent linkage between the CalB enzyme and the interior of a modified CCMV capsid [59]. Hereto, a Gly residue was introduced at the CCMV N-terminus, while an LPETG Sortase recognition sequence was introduced at the C-terminus of CalB. The enzyme Sortase A was then employed to generate CalB-LPETG-CCMV, which co-assembled with non-functionalized CCMV into CCMV capsids with encapsulated CalB. These enzymeloaded capsids were used to demonstrate that the CCMV nanocage protects encapsulated enzymes against proteolytic degradation. Yet another strategy was followed to encapsulate two different two-enzyme cascades inside CCMV capsids (Figure 3b) [60]. The enzymes in the pathways were functionalized with complementary single-stranded DNA sequences, which after hybridization yielded dual-enzyme complexes. In addition, the DNA strands introduced sufficient negative charges interacting with the positive CCMV capsid interior to allow reassembly of the protein cage around the enzyme complexes. Interestingly, the protein templated capsids had an altered architecture displaying $T=1$ icosahedral symmetry and a diameter of $20 \mathrm{~nm}$.

Recently, a protein block copolymer of CCMV and an elastin-like polypeptide (ELP) was developed with an added degree of control over CCMV capsid assembly [62]. Due to 
the stimulus-responsive behavior of the N-terminally fused ELP domain, CCMV assembly could be directed by increments in temperature and salt concentration. This ELPdirected assembly yielded smaller $18 \mathrm{~nm}$ CCMV capsids with $T=1$ icosahedral symmetry that were composed of 60 coat protein subunits. $\mathrm{pH}$-induced assembly was unaltered. Most importantly, these CCMV variants have been used for enzyme encapsulation in a nanoreactor context [59] and, combined with the ability to adjust the ELP sequence in order to allow self-assembly at nearly-physiological conditions, [63] this promises a great future for CCMV in the development of functional nanoreactors and artificial organelles.

\subsubsection{Bacteriophage $P_{22}$}

The bacteriophage P22 capsid is almost double the size of the CCMV capsid and is assembled out of 420 identical coat proteins around 100 to 330 copies of a scaffold protein (SP) $[64,65]$. This yields a pro capsid (PC) structure with a diameter of $58 \mathrm{~nm}$ and $T=7$ icosahedral symmetry, which is very well-suited for nanoreactor production. First of all, the SP can be modified and genetically fused to enzymes to easily facilitate their encapsulation inside P22 capsids [64-68]. Another aspect of the P22 capsid that is beneficial for nanoreactor production is the possibility to rearrange the capsid architecture by incubation at increased temperatures [64,65]. During 10 minutes at $65^{\circ} \mathrm{C}$, the SP is released from the PC capsid while it expands into a $64 \mathrm{~nm}$ EX nanocage. Alternatively, incubation at $75{ }^{\circ} \mathrm{C}$ for 20 minutes results in loss of coat proteins at the 5 -fold icosahedral vertices, generating twelve $10 \mathrm{~nm}$ holes in a wiffleball (WB) P22 capsid. Most interestingly, these morphological transitions can be used to control the activity of the encapsulated enzymes.

Douglas and coworkers have used the P22 capsid to produce nanoreactors that encapsulate enzymes [64-67], smallmolecule catalysts $[67,69]$ and even a three-enzyme cascade [68]. To achieve the latter, a genetic three-enzyme fusion to the P22 scaffold protein was prepared, which ensured that all three enzymes in the cascade were co-encapsulated with a known stoichiometry (Figure 3c). Flexible linkers between the individual protein domains facilitated quaternary structure formation to yield active enzymes. Encapsulation of the tetrameric $\beta$-glucosidase CelB, the dimeric ADP-dependent glucokinase GLUK and the monomeric ATP-dependent galactokinase GALK resulted in nanoreactors that could consume lactose to yield galactose-1-phosphate and glucose-6-phosphate. Alternatively, multiple enzymes were encapsulated at once by preparation of genetic fusions to the SP for every individual enzyme. This approach was already proven to be feasible for a two-subunit enzyme [66].

Despite its great promise, one of the biggest disadvantages of the P22 capsid for nanoreactor production is that these protein cages are generally loaded with enzymes in vivo, limiting the control over cargo encapsulation. In addition, in vivo assembly does not guarantee that all of the encapsulated enzymes are correctly folded and active. Very recently, Sharma et al. [70] demonstrated a method to overcome this difficulty by enabling in vitro assembly of and encapsulation in P22 capsids. Hereto, P22 capsids were produced in vivo and subsequently the chaotrope guanidine hydrochloride was added to remove the SP, yielding empty shells. These could be dissociated into coat protein subunits, which were combined with streptavidin-fused SP and wild type SP to allow capsid assembly. By repeating the chaotrope treatment, wild type SP could be specifically released from the capsids as the streptavidin-fused SP was too big to fit through the pores in the P22 capsids, allowing control over the packing density inside the particles. Although this approach was not used in the construction of a P22 nanoreactor yet, it holds great promise for the future.

\subsubsection{Bacteriophage MS2}

The icosahedral capsid of the bacteriophage MS2 is formed by self-assembly of 180 monomers and has a diameter of $27 \mathrm{~nm}$. While the native guest in this nanocage is a single-stranded RNA, enzymes that are fused to a DNA oligomer or a genetically encoded poly(anionic) tag can also interact with the MS2 RNA-binding motif, facilitating the encapsulation of these enzymes in the viral capsid [71]. This allows for the use of MS2 as a nanoreactor. The thirty-two pores of $2 \mathrm{~nm}$ width that are located in the protein shell allow influx and efflux of substrates and products respectively, which can be regulated by modification of the pore structure [72].

As a demonstration of the great promise of MS2 as a nanoreactor for biological applications, Giessen and Silver have used the MS2 capsid to develop an in vivo assembly system (Figure 3d) [73]. Hereto, a MS2-SpyTag and two enzymeSpyCatcher fusion proteins were produced. During capsid assembly in E. coli the SpyCatcher and SpyTag could form a covalent linkage, allowing loading of the MS2 capsid with both enzymes in vivo. Subsequently, the enzyme-loaded MS2 nanoreactors could be purified. Most interestingly, encapsulation of a two-enzyme catalytic cascade inside the MS2 capsid did not only enhance the stability of the enzymes in vitro, but also increased the enzymatic activity in vivo with $60 \%$ compared to the non-encapsulated enzymes. This work demonstrates great promise for the future, as similar systems can possibly be used to increase the yield of multi-enzyme cascades in biomanufacturing or alternatively be developed into artificial organelles.

\section{CONCLUDING REMARKS AND FUTURE PERSPECTIVES}

During the past couple of years great advances have been made in self-assembled peptide- and protein-based nanoreactors. Based on a fundamental interest in understanding enzyme and organelle origin and function, researchers have followed two distinct strategies. In mostly peptide-based systems, specific amino acids in positionally assembled fibrous structures give rise to catalytic assembly, whereas in protein nanocage-based systems whole enzymes or metal catalysts are incorporated in nanoreactors. Despite these diverging strategies, in both systems the transition from incorporation of a single catalyst to incorporation of multi-catalytic systems has been made. Especially hydrogels and protein nanocage systems hold great promise for incorporation 
of multi-enzyme pathways or combinations of enzymes and organic catalysts.

Although big steps have been taken, some important challenges and possibilities for further development still remain in the field of peptide- and protein-based nanoreactors. First of all, promising self-assembled systems such as elastin-like polypeptides (ELPs) [74] and designer protein nanocages $[75,76]$ could be developed into nanoreactors, adding to the variety of available systems. Especially the latter system could be useful, when applying design strategies that are similar to those used in nanoreactor construction from DNA origami [5]. In addition, strategies that are applied in one particular system might be examined as general strategies to introduce novel functionality in other systems. For example, the enzyme incorporation method based on charge complementarity that was described for AaLS [51,52], could also be used in other protein nanocage systems. Alternatively, distinct positional assembly strategies that were applied in the generation of catalytic peptide fibers (section 2.1) could be combined to yield novel fibers with dual-catalytic activity.

Other steps that should be taken involve the applications of protein and peptide based nanoreactors. Key to the relevance of these systems is a demonstration of the added value of a compartmentalized system or positional assembly of catalysts. Therefore research should focus on the evaluation of efficiency, specificity and solvent compatibility of catalysis. In addition, the compatibility of the nanoreactors with living systems should be assessed. Such developments would increase the applicability of protein and peptide based nanoreactors in biomanufacturing, therapeutics and in vivo enzyme and organelle mimics. Another outstanding challenge is to mimic nature even more by incorporating spatiotemporal control into peptide- and protein-based nanoreactors. The self-assembling nature of the systems that are described in this review can be highly beneficial for such regulation as a trigger could be designed to induce the formation of the supramolecular systems and thereby activate catalysis.

Finally, in the future the assembly of catalytic peptides and proteins could be taken to the next level. Recently, hierarchical organization of protein assemblies into array structures has gained the interest of researchers. Electrostatic interactions, metal-ligand interactions, molecular recognition and protein-protein interactions are known to drive this hierarchical self-assembly [77] and CCMV [78], P22 [79] and ferritin [80] nanocages have been incorporated in crystalline structures and metamaterials. Combining this hierarchical organization with protein nanocage-based nanoreactors can give rise to array structures that incorporate various catalytic functions with high level of positional control.

\section{AUTHOR INFORMATION}

\section{Corresponding Author}

*E-mail: J.C.M.v.Hest@tue.nl

\section{ACKNOWLEDGEMENTS}

The authors would like to acknowledge the ERC Advanced grant Artisym 694120 and the Dutch Ministry of Education,
Culture and Science (Gravitation program 024.001.035) for funding.

\section{SUMMARY OF KEY REFERENCES}

Papers of particular interest, published within the period of review, have been highlighted as: * of special interest; $* *$ of outstanding interest.

[11]*: This pioneering paper describes the roles of the alkyl chains and the peptide parts of self-assembling peptide amphiphiles for fiber formation and catalysis.

$[13]^{*}:$ In this paper the first nanotube catalyst, based on metal-coordinating bolaamphiphilic peptides, was reported that catalyzed asymmetric reactions with high efficiency and stereo selectivity.

[14]**: This paper reported on three similar peptide amphiphiles with different catalytic residues that co-assembled into catalytic nanofibers, bringing the catalytic residues together in a triad. With the use of molecular imprinting the catalytic activity was further enhanced.

[20]*: Here, a thorough investigation of the effects of substitutions of polar and apolar residues in an amyloid peptide sequence on the esterase activity of assembled fibers is presented.

[21]*: In this work two similar amyloid peptides with different catalytic residues were co-assembled into catalytic nanofibers.

[22]*: This paper reported on the incorporation of three catalytic residues from a serine protease into one single amyloid peptide. Self-assembly yielded catalytic nanofibers.

[23]**: In this paper a catalytic sequence was fused to an amyloid sequence and a collagen peptide sequence. Only the amyloid fibers displayed good catalytic activity, demonstrating the importance of choosing the correct peptide platform for the display of the catalytic domains.

[28]*: This pioneering paper was one of the first to report on catalytic peptide-based hydrogels. Close proximity of catalytic groups as well as hydrophobic pockets in the hydrogel network are identified as key factors for catalysis.

[29]*: In this work it was demonstrated that hydrophobic regions as well as active site accessibility are key factors determining the activity of catalytic peptide hydrogels.

[30]**: This paper reports on a catalytic hydrogel with dual catalytic functionality. By making use of a bolaamphiphilic peptide and an amphiphilic peptide, the catalytic gelators self-sorted into a hydrogel network consisting of two types of molecular fibers. In this way the activity of the incompatible catalysts was maintained in the hydrogel network.

[31]**: In this paper a peptide-based sol-gel system is described in which two catalysts cooperate.

[35]*: This work describes the incorporation of cytochrome P450 and two redox partners into a protein-based hydrogel network.

[38]*: This paper reports the exterior functionalization of a zucchini yellow mosaic virus particle via antibodies specific for the viral coat proteins and attachment of an antibody binding peptide to a protein of interest.

[39]*: In this publication the surface functionalization of tobacco mosaic virus with enzymes is described. The employed strategy encompasses coupling of a maleimide-biotin linker to an engineered cysteine on the viral coat protein and further functionalization with streptavidin-conjugated enzymes.

[41]*: In this work the fd bacteriophage was functionalized with enzymes via a two-antibody immunological strategy. Enhanced activity of the enzymes on the virus scaffold was demonstrated.

[53]*: This paper reports the encapsulation of enzymes in AaLS protein nanocages via genetic fusion of the enzymes to positively supercharged GFP and electrostatic interaction with the negatively charged AaLS interior. This strategy could be generally applied in protein nanocage encapsulation.

[55]**: In this work two enzymes were incorporated in an AaLs protein nanocage at once by means of electrostatic interactions. The nanoreactor mimicked the activity of carboxysomes.

[59]*: Here, the sortase-mediated covalent attachment of an enzyme to the interior of CCMV capsids is described. With this strategy very efficient encapsulation of an enzyme was achieved.

[60]**: This paper reports on the encapsulation of an enzyme cascade into CCMV nanocages. Negatively charged DNA tags were attached to the enzymes of interest, which allowed the formation of an enzyme complex 
with sufficient anionic charges to be encapsulated by the positively charged CCMV interior surface.

[62]**: This publication describes a novel self-assembly trigger for CCMV by production of a genetic fusion between an ELP and the CCMV $\mathrm{N}$-terminus. The resulting ELP-CCMV proteins could still self-assemble by a $\mathrm{pH}$ trigger, but in addition self-assembly could be induced by a salt or temperature trigger.

[66]*: In this work a hydrogen producing nanoreactor was created via encapsulation of a hydrogenase in a P22 nanocage through genetic fusion to the scaffold protein. Encapsulation increased the stability of the hydrogenase.

[68]**: Here, the encapsulation of a three enzyme cascade into a single P22 nanocage is reported. The enzymes were genetically fused to each other and the P22 scaffold protein, which led to co-encapsulation with known stoichiometries.

[70]**: This work describes for the first time the in vitro encapsulation of a protein within P22 capsids. In addition, a strategy is discussed for varying the packing density inside the nanocage, which can be used to study the effects of crowding and confinement on enzyme activity.

[73]**: In this paper the in vivo encapsulation of a two-enzyme cascade inside MS2 nanocages is described. It is demonstrated that encapsulation increases the stability and improves the in vivo activity of the enzymes.

\section{REFERENCES}

[1] Dong Z, Yongguo Wang, Yin Y, Liu J. Supramolecular enzyme mimics by self-assembly. Curr Opin Colloid Interface Sci 2011;16:451-8. doi:10.1016/j.cocis.2011.08.006.

[2] Schoffelen S, van Hest JCM. Multi-enzyme systems: bringing enzymes together in vitro. Soft Matter 2012;8:1736-46. doi:10.1039/c1sm06452e.

[3] Schoonen L, Van Hest JCM. Compartmentalization Approaches in Soft Matter Science: From Nanoreactor Development to Organelle Mimics. Adv Mater 2016;28:1109-28. doi:10.1002/adma.201502389.

[4] Quin MB, Wallin KK, Zhang G, Schmidt-Dannert C. Spatial organization of multi-enzyme biocatalytic cascades. Org Biomol Chem 2017;15:4260-71. doi:10.1039/C7OB00391A

[5] Zhao Z, Fu J, Dhakal S, Johnson-Buck A, Liu M, Zhang T, et al. Nanocaged enzymes with enhanced catalytic activity and increased stability against protease digestion. Nat Commun 2016;7:10619. doi:10.1038/ncomms10619.

[6] Lawrence AD, Frank S, Newnham S, Lee MJ, Brown IR, Xue $\mathrm{WF}$, et al. Solution structure of a bacterial microcompartment targeting peptide and its application in the construction of an ethanol bioreactor. ACS Synth Biol 2014;3:454-65. doi:10.1021/sb4001118.

[7] Held M, Kolb A, Perdue S, Hsu S-Y, Bloch SE, Quin MB, et al. Engineering formation of multiple recombinant Eut protein nanocompartments in E. coli. Sci Rep 2016;6:24359. doi:10.1038/srep24359.

[8] Quin MB, Perdue SA, Hsu SY, Schmidt-Dannert C. Encapsulation of multiple cargo proteins within recombinant Eut nanocompartments. Appl Microbiol Biotechnol 2016;100:9187200. doi:10.1007/s00253-016-7737-8.

[9] Khalily MA, Ustahuseyin O, Garifullin R, Genc R, Guler MO. A supramolecular peptide nanofiber templated Pd nanocatalyst for efficient Suzuki coupling reactions under aqueous conditions. Chem Commun 2012;48:11358-60. doi:10.1039/c2cc36228g.

[10] Fry HC, Garcia JM, Medina MJ, Ricoy UM, Gosztola DJ, Nikiforov MP, et al. Self-assembly of highly ordered peptide amphiphile metalloporphyrin arrays. J Am Chem Soc 2012;134:14646-9. doi:10.1021/ja304674d.

[11] Guler MO, Stupp SI. A self-assembled nanofiber peptide catalyst for ester hydrolysis. J Am Chem Soc 2007;129:12082-3. doi:10.1021/ja075044n.

[12] Bélières M, Chouini-Lalanne N, Déjugnat C. Synthesis, selfassembly, and catalytic activity of histidine-based structured lipopeptides for hydrolysis reactions in water. RSC Adv 2015;5:35830-42. doi:10.1039/C5RA02853A.

[13] Jiang J, Meng Y, Zhang L, Liu M. Self-Assembled Single-Walled Metal-Helical Nanotube ( M-HN ): Creation of Efficient Supramolecular Catalysts for Asymmetric Reaction. J Am Chem Soc 2016;138:15629-35. doi:10.1021/jacs.6b08808.
Wang M, Lv Y, Liu X, Qi W, Su R, He Z. Enhancing the Activity of Peptide-Based Artificial Hydrolase with Catalytic Ser/His/Asp Triad and Molecular Imprinting. ACS Appl Mater Interfaces 2016;8:14133-41. doi:10.1021/acsami.6b04670.

[15] Gulseren G, Yasa IC, Ustahuseyin O, Tekin ED, Tekinay AB, Guler MO. Alkaline phosphatase-mimicking peptide nanofibers for osteogenic differentiation. Biomacromolecules 2015;16:2198-208. doi:10.1021/acs.biomac.5b00593.

[16] Gulseren G, Khalily MA, Tekinay AB, Guler MO. Catalytic supramolecular self-assembled peptide nanostructures for ester hydrolysis. J Mater Chem B 2016;4:4605-11. doi:10.1039/C6TB00795C

[17] Eisenberg D, Jucker M. The amyloid state of proteins in human diseases. Cell 2012:148:1188-203. doi:10.1016/j.cell.2012.02.022.

[18] Omosun TO, Hsieh M-C, Childers WS, Das D, Mehta AK, Anthony NR, et al. Catalytic diversity in self-propagating peptide assemblies. Nat Chem 2017;9:805-9. doi:10.1038/nchem.2738.

[19] Al-Garawi ZS, McIntosh B, Neill-Hall D, Hatimy A, Sweet S, Bagley MC, et al. The amyloid architecture provides a scaffold for enzyme-like catalysts. Nanoscale 2017;9:10773-83. doi:10.1039/C7NR02675G

[20] Rufo CM, Moroz YS, Moroz O V., Stöhr J, Smith T a., Hu X, et al. Short peptides self-assemble to produce catalytic amyloids. Nat Chem 2014;6:303-9. doi:10.1038/nchem.1894.

[21] Zhang C, Xue X, Luo Q, Li Y, Yang K, Zhuang X, et al. Selfassembled peptide nanofibers designed as biological enzymes for catalyzing ester hydrolysis. ACS Nano 2014;8:11715-23. doi:10.1021/nn5051344.

[22] Wong YM, Masunaga H, Chuah JA, Sudesh K, Numata K. Enzyme-Mimic Peptide Assembly to Achieve Amidolytic Activity. Biomacromolecules 2016;17:3375-85. doi:10.1021/acs.biomac.6b01169.

[23] Maeda Y, Fang J, Ikezoe Y, Pike DH, Nanda V, Matsui H. Molecular Self-Assembly Strategy for Generating Catalytic Hybrid Polypeptides. PLoS One 2016;11:e0153700. doi:10.1371/journal.pone.0153700.

[24] Xu W, Hong Y, Hu Y, Hao J, Song A. Ultrafine Au and Ag Nanoparticles Synthesized from Self-Assembled Peptide Fibers and Their Excellent Catalytic Activity. ChemPhysChem 2016;17:2157-63. doi:10.1002/cphc.201600182.

[25] Du X, Zhou J, Shi J, Xu B. Supramolecular Hydrogelators and Hydrogels: From Soft Matter to Molecular Biomaterials. Chem Rev 2015;115:13165-307. doi:10.1021/acs.chemrev.5b00299.

[26] Rodríguez-Llansola F, Escuder B, Miravet JF. Switchable perfomance of an L-proline-derived basic catalyst controlled by supramolecular gelation. J Am Chem Soc 2009;131:11478-84. doi:10.1021/ja902589f

[27] Rodríguez-Llansola F, Miravet JF, Escuder B. A supramolecular hydrogel as a reusable heterogeneous catalyst for the direct aldol reaction. Chem Commun 2009;0:7303-5. doi:10.1039/b916250j. Singh N, Conte MP, Ulijn R V., Miravet JF, Escuder B. Insight into the esterase like activity demonstrated by an imidazole appended self-assembling hydrogelator. Chem Commun 2015;51:13213-6. doi:10.1039/C5CC04281J.

[29] Tena-Solsona M, Nanda J, Díaz-Oltra S, Chotera A, Ashkenasy G, Escuder B. Emergent Catalytic Behavior of Self-Assembled Low Molecular Weight Peptide-Based Aggregates and Hydrogels. Chem - A Eur J 2016;22:6687-94. doi:10.1002/chem.201600344.

[30] Singh N, Zhang K, Angulo-Pachón CA, Mendes E, van Esch JH, Escuder B. Tandem reactions in self-sorted catalytic molecular hydrogels. Chem Sci 2016;7:5568-72. doi:10.1039/C6SC01268J.

[31] Singh N, Escuder B. Competition versus Cooperation in Catalytic Hydrogelators for anti -Selective Mannich Reaction. Chem - A Eur J 2017;23:9946-51. doi:10.1002/chem.201701724.

[32] Lin CY, Liu JC. Modular protein domains: An engineering approach toward functional biomaterials. Curr Opin Biotechnol 2016;40:56-63. doi:10.1016/j.copbio.2016.02.011.

[33] Ramirez M, Guan D, Ugaz V, Chen Z. Intein-Triggered Artificial Protein Hydrogels That Support the Immobilization of Bioactive Proteins. J Am Chem Soc 2013;135:5290-3. doi:10.1021/ja401075s.

[34] Guan D, Ramirez M, Shao L, Jacobsen D, Barrera I, Lutkenhaus 
J, et al. Two-component protein hydrogels assembled using an engineered disulfide-forming protein-ligand pair. Biomacromolecules 2013;14:2909-16. doi:10.1021/bm400814u.

[35] Tan CY, Hirakawa H, Nagamune T. Supramolecular protein assembly supports immobilization of a cytochrome P450 monooxygenase system as water-insoluble gel. Sci Rep 2015;5:8648-55. doi:10.1038/srep08648.

[36] Zhang Y, Ardejani MS, Orner BP. Design and Applications of Protein-Cage-Based Nanomaterials. Chem - An Asian J 2016:2814-28. doi:10.1002/asia.201600769.

[37] Carette N, Engelkamp H, Akpa E, Pierre SJ, Cameron NR, Christianen PCM, et al. A virus-based biocatalyst. Nat Nanotechnol 2007;2:226-9. doi:10.1038/nnano.2007.76.

[38] Pille J, Cardinale D, Carette N, Di Primo C, Besong-Ndika J, Walter J, et al. General strategy for ordered noncovalent protein assembly on well-defined nanoscaffolds. Biomacromolecules 2013;14:4351-9. doi:10.1021/bm401291u.

[39] Koch C, Wabbel K, Eber FJ, Krolla-Sidenstein P, Azucena C, Gliemann H, et al. Modified TMV Particles as Beneficial Scaffolds to Present Sensor Enzymes. Front Plant Sci 2015;6:1137. doi:10.3389/fpls.2015.01137.

[40] Bäcker M, Koch C, Eiben S, Geiger F, Eber F, Gliemann H, et al. Tobacco mosaic virus as enzyme nanocarrier for electrochemical biosensors. Sensors Actuators B Chem 2017;238:716-22. doi:10.1016/j.snb.2016.07.096.

[41] Patel AN, Anne A, Chovin A, Demaille C, Grelet E, Michon T, et al. Scaffolding of Enzymes on Virus Nanoarrays: Effects of Confinement and Virus Organization on Biocatalysis. Small 2017;13:1603163. doi:10.1002/smll.201603163.

[42] Bode SA, Minten IJ, Nolte RJM, Cornelissen JJLM. Reactions inside nanoscale protein cages. Nanoscale 2011;3:2376-89. doi:10.1039/c0nr01013h.

[43] Maity B, Fujita K, Ueno T. Use of the confined spaces of apoferritin and virus capsids as nanoreactors for catalytic reactions. Curr Opin Chem Biol 2015;25:88-97. doi:10.1016/j.cbpa.2014.12.026.

[44] Kanbak-Aksu S, Nahid Hasan M, Hagen WR, Hollmann F, Sordi D, Sheldon RA, et al. Ferritin-supported palladium nanoclusters: selective catalysts for aerobic oxidations in water. Chem Commun 2012;48:5745-7. doi:10.1039/c2cc31401k.

[45] Olsen CR, Smith TJ, Embley JS, Maxfield JH, Hansen KR, Peterson JR, et al. Permanganate-based synthesis of manganese oxide nanoparticles in ferritin. Nanotechnology 2017;28:19560110. doi:10.1088/1361-6528/aa68ae.

[46] Pulsipher KW, Honig S, Deng S, Dmochowski IJ. Controlling gold nanoparticle seeded growth in thermophilic ferritin protein templates. J Inorg Biochem 2017;174:169-76. doi:10.1016/j.jinorgbio.2017.06.012.

[47] Liu X, Wei W, Yuan Q, Zhang X, Li N, Du Y, et al. Apoferritin$\mathrm{CeO} 2$ nano-truffle that has excellent artificial redox enzyme activity. Chem Commun 2012;48:3155-7. doi:10.1039/c1cc15815e.

[48] Renggli K, Nussbaumer MG, Urbani R, Pfohl T, Bruns N. A chaperonin as protein nanoreactor for atom-transfer radical polymerization. Angew Chemie - Int Ed 2014;53:1443-7. doi:10.1002/anie.201306798.

[49] Renggli K, Sauter N, Rother M, Nussbaumer MG, Urbani R, Pfohl T, et al. Biocatalytic atom transfer radical polymerization in a protein cage nanoreactor. Polym Chem 2017;8:2133-6. doi:10.1039/C6PY02155G

[50] Nussbaumer MG, Bisig C, Bruns N. Using the dendritic polymer PAMAM to form gold nanoparticles in the protein cage thermosome. Chem Commun 2016;52:10537-9. doi:10.1039/C6CC04739D.

[51] Wörsdörfer B, Pianowski Z, Hilvert D. Efficient in vitro encapsulation of protein cargo by an engineered protein container. J Am Chem Soc 2012;134:909-11. doi:10.1021/ja211011k.

[52] Zschoche R, Hilvert D. Diffusion-Limited Cargo Loading of an Engineered Protein Container. J Am Chem Soc 2015;137:1612132. doi:10.1021/jacs.5b10588.

[53] Azuma Y, Zschoche R, Tinzl M, Hilvert D. Quantitative Packaging of Active Enzymes into a Protein Cage. Angew Chemie - Int Ed 2016;55:1531-4. doi:10.1002/anie.201508414.
[55]

inside engineered protein cages. Chem Commun 2016;52:104236. doi:10.1039/C6CC05301G

Frey R, Mantri S, Rocca M, Hilvert D. Bottom-up Construction of a Primordial Carboxysome Mimic. J Am Chem Soc 2016;138:10072-5. doi:10.1021/jacs.6b04744.

[56] Comellas-Aragonès M, Engelkamp H, Claessen VI, Sommerdijk NAJM, Rowan AE, Christianen PCM, et al. A virus-based singleenzyme nanoreactor. Nat Nanotechnol 2007;2:635-9. doi:10.1038/nnano.2007.299.

[57] Liu A, Traulsen CH-H, Cornelissen JJLM. Nitroarene Reduction by a Virus Protein Cage Based Nanoreactor. ACS Catal 2016;6:3084-91. doi:10.1021/acscatal.6b00106.

[58] Minten IJ, Hendriks LJA, Nolte RJM, Cornelissen JJLM. Controlled Encapsulation of Multiple Proteins in Virus Capsids. J Am Chem Soc 2009;131:17771-3. doi:10.1021/ja907843s.

[59] Schoonen L, Nolte RJM, van Hest JCM. Highly efficient enzyme encapsulation in a protein nanocage: towards enzyme catalysis in a cellular nanocompartment mimic. Nanoscale 2016:14467-72. doi:10.1039/C6NR04181G.

[60] Brasch M, Putri RM, de Ruiter MV, Luque D, Koay MST, Castón JR, et al. Assembling Enzymatic Cascade Pathways inside VirusBased Nanocages Using Dual-Tasking Nucleic Acid Tags. J Am Chem Soc 2017;139:1512-9. doi:10.1021/jacs.6b10948.

[61] Minten IJ, Claessen VI, Blank K, Rowan AE, Nolte RJM, Cornelissen JJLM. Catalytic capsids: the art of confinement. Chem Sci 2011;2:358-62. doi:10.1039/c0sc00407c.

[62] Van Eldijk MB, Wang JC-Y, Minten IJ, Li C, Zlotnick A, Nolte RJM, et al. Designing two self-assembley mechanisms into one viral capsid protein. J Am Chem Soc 2012;134:18506-9. doi:10.1021/ja308132z.Designing.

[63] Schoonen L, Maas RJM, Nolte RJM, van Hest JCM. Expansion of the assembly of cowpea chlorotic mottle virus towards nonnative and physiological conditions. Tetrahedron 2017;73:496871. doi:10.1016/j.tet.2017.04.038.

[64] Patterson DP, Prevelige PE, Douglas T. Nanoreactors by programmed enzyme encapsulation inside the capsid of the bacteriophage P22. ACS Nano 2012;6:5000-9. doi:10.1021/nn300545z.

[65] Patterson DP, Schwarz B, El-Boubbou K, van der Oost J, Prevelige PE, Douglas T. Virus-like particle nanoreactors: programmed encapsulation of the thermostable CelB glycosidase inside the P22 capsid. Soft Matter 2012;8:10158-66. doi: $10.1039 / \mathrm{c} 2 \mathrm{sm} 26485 \mathrm{~d}$.

[66] Jordan PC, Patterson DP, Saboda KN, Edwards EJ, Miettinen HM, Basu G, et al. Self-assembling biomolecular catalysts for hydrogen production. Nat Chem 2015;8:179-85. doi:10.1038/nchem.2416.

[67] Patterson D, Edwards E, Douglas T. Hybrid Nanoreactors: Coupling Enzymes and Small-Molecule Catalysts within VirusLike Particles. Isr J Chem 2015;55:96-101. doi:10.1002/ijch.201400092.

[68] Patterson DP, Schwarz B, Waters RS, Gedeon T, Douglas T. Encapsulation of an Enzyme Cascade within the Bacteriophage P22 Virus-Like Particle. ACS Chem Biol 2014;9:359-365. doi:10.1021/cb4006529.

[69] Edwards E, Roychoudhury R, Schwarz B, Jordan P, Lisher J Uchida $\mathrm{M}$, et al. Co-localization of catalysts within a protein cage leads to efficient photochemical $\mathrm{NADH}$ and/or hydrogen production. J Mater Chem B 2016;4:5375-84. doi:10.1039/C6TB01175F

[70] Sharma J, Uchida M, Miettinen HM, Douglas T. Modular interior loading and exterior decoration of a virus-like particle. Nanoscale 2017;9:10420-30. doi:10.1039/C7NR03018E.

[71] Glasgow JE, Capehart SL, Francis MB, Tullman-Ercek D. Osmolyte-mediated encapsulation of proteins inside MS2 viral capsids. ACS Nano 2012;6:8658-64. doi:10.1021/nn302183h.

[72] Glasgow JE, Asensio MA, Jakobson CM, Francis MB, TullmanErcek D. Influence of Electrostatics on Small Molecule Flux through a Protein Nanoreactor. ACS Synth Biol 2015;4:1011-9. doi:10.1021/acssynbio.5b00037.

[73] Giessen TW, Silver PA. A Catalytic Nanoreactor Based on in Vivo Encapsulation of Multiple Enzymes in an Engineered Protein Nanocompartment. ChemBioChem 2016;17:1931-5. doi:10.1002/cbic. 201600431 .

[74] Kowalczyk T, Hnatuszko-Konka K, Gerszberg A, Kononowicz 
AK. Elastin-like polypeptides as a promising family of genetically-engineered protein based polymers. World J Microbiol Biotechnol 2014;30:2141-52. doi:10.1007/s11274014-1649-5.

[75] Bale JB, Gonen S, Liu Y, Sheffler W, Ellis D, Thomas C, et al. Accurate design of megadalton-scale two-component icosahedral protein complexes. Science (80- ) 2016;353:389-94. doi:10.5061/dryad.8c65s

[76] Heddle JG, Chakraborti S, Iwasaki K. Natural and artificial protein cages: design, structure and therapeutic applications. Curr Opin Struct Biol 2017;43:148-55. doi:10.1016/j.sbi.2017.03.007.

[77] Yang G, Wu L, Chen G, Jiang M. Precise protein assembly of array structures. Chem Commun 2016;52:10595-605. doi:10.1039/C6CC04190F

[78] Liljeström V, Mikkilä J, Kostiainen MA. Self-assembly and modular functionalization of three-dimensional crystals from oppositely charged proteins. Nat Commun 2014;5:4445. doi:10.1038/ncomms5445.

[79] Palchoudhury S, Zhou Z, Ramasamy K, Okirie F, Prevelige PE, Gupta A. Self-assembly of P22 protein cages with polyamidoamine dendrimer and inorganic nanoparticles. J Mater Res 2017;32:465-72. doi:10.1557/jmr.2016.439.

[80] Mikkilä J, Anaya-Plaza E, Liljeström V, Caston JR, Torres T, De La Escosura A, et al. Hierarchical organization of organic dyes and protein cages into photoactive crystals. ACS Nano 2016;10:1565-71. doi:10.1021/acsnano.5b07167.

Table 1: Self-assembled peptide- and protein-based nanoreactors and their catalytic activities

\begin{tabular}{|c|c|}
\hline & System \\
\hline \multirow{13}{*}{ 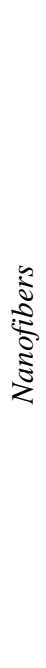 } & Lauryl-VVAGHH-NH ${ }_{2}$ \\
\hline & H-HK(H)LLLAAAL(Palmitoyl)- $\mathrm{NH}_{2}$ \\
\hline & $\mathrm{C}_{8}-\mathrm{GGH}-\mathrm{OH}$ \\
\hline & HO-Glu-CO-C16-CO-Glu-OH \\
\hline & Fmoc-FFX-OH $(X=S, H, D)$ \\
\hline & Lauryl-VVAGHH-NH${ }_{2}$ \\
\hline & Lauryl-VVAGX $\left(\mathrm{X}=\mathrm{D}-\mathrm{NH}_{2}, \mathrm{H}-\mathrm{NH}_{2}, \mathrm{~S}-\mathrm{OH}\right)$ \\
\hline & Ac-XLVFFAL-NH $2(X=K, R, H)$ \\
\hline & Ac-IHIHIXI-NH $2(X=Y, Q)$ \\
\hline & H-XSGQQKFQFQFEQQ-NH ${ }_{2}(X=\mathrm{G}, \mathrm{H}, \mathrm{R})$ \\
\hline & Ac-FGFHFSFDF-NH ${ }_{2}$ \\
\hline & H-SMESLSKTHHYRFFKLVFF-OH \\
\hline & Ac-FFACD-OH \\
\hline \multirow{7}{*}{ 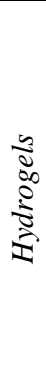 } & ProVal8 \\
\hline & ProValDoc \\
\hline & HisVal8 \\
\hline & SucVal8 + ProValDoc \\
\hline & $\mathrm{H}-\mathrm{PFE}-\mathrm{C}_{12}$ \\
\hline & CutA-Tip1 lig + CutA-Tip1 \\
\hline & PTDH-PCNA-enzyme \\
\hline
\end{tabular}

Ferritin

Thermosome

Lumazine synthetase

Cowpea chlorotic mottle virus

Bacteriophage P22

Bacteriophage MS2
Suzuki-Miyaura couplings of aryl iodides [9]

Ester hydrolysis [11]

Hydrolysis [12]

Mukaiyama aldol reaction [13]; Diels-Alder reaction [13]

Hydrolysis [14]

Phosphate hydrolysis [15]

Ester hydrolysis [16]

Poly-imine condensation [18]; retro-aldol conversion [18]

Ester hydrolysis [19,20]

Ester hydrolysis [21]

Amidolytic activity [22]

Ester hydrolysis [23]

Reductive activity [24]

Nitroaldol reaction [26]

Direct aldol reaction [27]

Ester hydrolysis [28]

One-pot deacetalization-aldol tandem reactions [30]; anti-selective Mannich reactions [31]

Aldol reaction [29]

Electroreduction of oxygen [34]

Monooxygenation [35]

Aerobic oxidation of alcohols in water [44]; templated mineralization of $\mathrm{MnO}_{2}$ nanoparticles [45]; templated biomineralization of gold nanoparticles [46]; ROS scavenging activity [47]

Atom-transfer radical polymerization [48,49]; Templated biomineralization of gold nanoparticles [50]

Kemp eliminase activity [53]; cyclohexylamine oxidase [53]; catalase peroxidase activity [53]; NADH oxidase activity [53]; ascorbate peroxidase catalyzed polymerization of 3,3-diaminobenzidine [54]; carboxysome-mimetic activity [55]

Peroxidase activity [56]; nitroarene reduction [57]; lipase activity $[59,61]$; two-step conversion of glucose to gluconic acid and D-gluconate-6-phosphate [60]

Alcohol dehydrogenase activity [64]; hydrolase activity [65,68]; hydrogenase activity [66]; phosphorylase activity [68]; reductive activity [67]; NADH and hydrogen production [69]

Phosphatase activity [71,72]; two-step production of indigo from Ltryptophan [73] 


\section{Graphical Abstract}

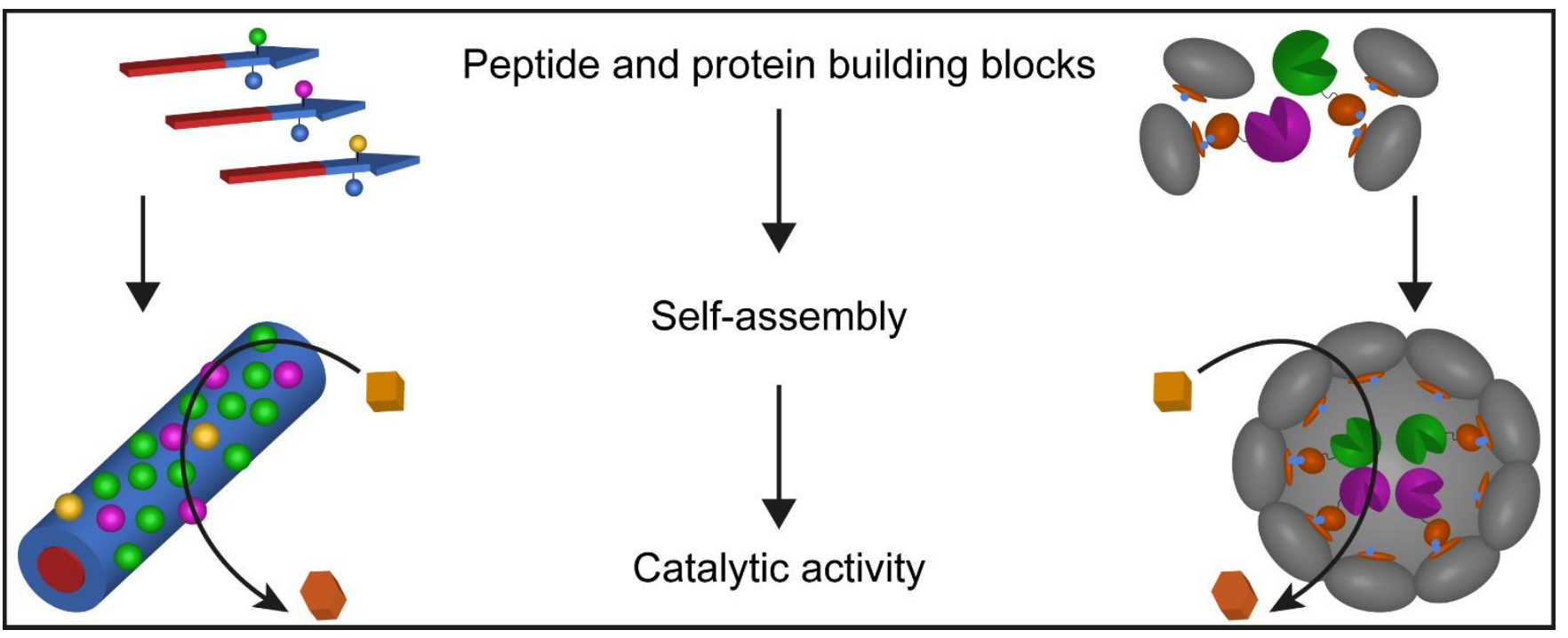

